\title{
Edukasi pada Pasien dan Keluarga sebagai Partner dalam Pencegahan Cedera
}

\author{
Queen Agave (queenasiregar@gmail.com)
}

\section{LATAR BELAKANG}

Hampir setiap tindakan medis menyimpan potensi resiko. Banyaknya jenis obat, jenis pemeriksaan dan prosedur, serta jumlah pasien dan staf Rumah Sakit yang cukup besar, merupakan hal yang potensial bagi terjadinya kesalahan medis (medical errors). Peran aktif keluarga dan pasien sebagai partner dalam pelayanan kesehatan untuk mencegah terjadinya bahaya disini sangat dibutuhkan, karena perawat tidak selalu berada diposisi pasien. Keluarga merupakan unit paling dekat dengan pasien, dan merupakan perawat utama bagi pasien. Keluarga berperan dalam menentukan cara atau perawatan yang diperlukan pasien di rumah sakit. Keberhasilan perawat di rumah sakit akan sia-sia jika tidak diteruskan di rumah yang kemudian mengakibatkan pasien harus dirawat kembali (kambuh). Peran serta keluarga sejak awal perawatan di rumah sakit akan meningkatkan kemampuan keluarga merawat pasien di rumah sehingga memungkinkan pasien tidak kambuh atau dapat dicegah.

Keterlibatan pasien dan keluarga pasien dalam mengelola pasien di rumah sakit menunjukkan hal yang luar biasa. Hasilnya pasien dan keluarga pasien yang dilibatkan dalam pengambilan keputusan secara bersama-sama dalam perawatan dan menjadikan pasien sebagai mitra dapat meningkatkan optimalisasi kesembuhan pasien, selain itu dengan melibatkan anggota keluarga seperti berpartisipasi dalam koordinasi keperawatan sangat penting. Keluarga merupakan bagian dari tim pengobatan dan perawatan. Apalagi di Indonesia dengan kultur sosialnya tinggi ditambah keterbatasan jumlah perawat di rumah sakit sehingga tugas merawat orang sakit yang dirawat di rumah sakit umumnya dilakukan oleh keluarga yang menjaga. Sementara perawat di rumah sakit yang seharusnya merawat orang sakit juga harus melakukan tugas-tugas yang lain di bangsal perawatan. Maka, peran keluarga penting untuk memantau kebutuhan pasien dari laporan perawat atau jika perlu malakukan komunikasi langsung. 


\section{METODE}

Metode yang digunakan dalam penulisan ini menggunakan metode literature. Metode literature merupakan metode pengumpulan data dengan cara membaca buku-buku dan situs-situs internet yang mendukung dan menunjang dalam pembuatan dan penyusunan laporan, sekaligus dijadikan sebagai landasan dalam penulisan laporan. 


\section{HASIL}

Rumah sakit harus mendidik pasien dan keluarganya tentang kewajiban dan tanggung jawab pasien dalam asuhan keperawatan. Kriterianya adalah keselamatan dalam pemberian pelayanan dapat ditingkatkan dengan keterlibatan pasien sebagai partner dalam proses pelayanan. Karena itu, di rumah sakit harus ada sistem dan mekanisme mendidik pasien dan keluarganya tentang kewajiban dan tanggung jawab pasien dalam asuhan keperawatan. Dengan pendidikan tersebut diharapkan pasien dan keluarga dapat:

a) Memberikan info yang benar, jelas, lengkap dan jujur,

b) Mengetahui kewajiban dan tanggung jawab,

c) Mengajukan pertanyaan untuk hal yang tidak dimengerti,

d) Memahami dan menerima konsekuensi pelayanan,

e) Mematuhi instruksi dan menghormati peraturan rumah sakit,

f) Memperlihatkan sikap menghormati dan tenggang rasa,

g) Memenuhi kewajiban finansial yang disepakati.

Pasien dan keluarganya mempunyai hak untuk mendapatkan informasi tentang rencana dan hasil pelayanan termasuk kemungkinan terjadinya insiden. Fasilitas pelayanan kesehatan harus mendidik pasien dan keluarganya tentang kewajiban dan tanggung jawab pasien dalam asuhan pasien.Setelah mendapatkan edukasi tentang pencegahan terjadinya bahaya dalam pelayanan, pasien dan keluarga menerapkan system pelayanan kesehatan tersebut .

Komponen yang dibutuhkan untuk tercapainya suatu kerjasama tim yang efektif Menurut O'Daniel, komponen kerjasama tim yang efektif, yaitu komunikasi terbuka, lingkungan yang leluasa, memiliki tujuan yang jelas, peran dan tugas yang jelas bagi angota-anggota tim, saling menghormati, berbagi tanggung jawab demi kesuksesan tim, keseimbangan patisipasi setiap anggota dalam mengemban tugas, pengakuan dan pengolahan konflik, spesifikasi yang jelas mengenai wewenang dan akuntabilitas, mengetahui secara jelas prosedur pengambilan keputusan, berkomunikasi dan berbagi informasi secara teratur dan rutin, lingkungan yang mendukung (termasuk akses ke sumber daya yang dibutuhkan), dan mekanisme untuk mengevaluasi hasil dan menyesuaikan sesuai peraturan yang berlaku. 


\section{PEMBAHASAN}

A. Peran keluarga secara aktif dalam menjaga keselamatan pasien dipelyanan kesehatan adalah

1. Memberikan informasi yang benar, jelas, lengkap dan jujur

2. Mengetahui dan melaksanakan kewajiban serta tanggung jawab pasien maupun keluarga.

3. Mengajukan pertanyaan-pertanyaan untuk hal yang tidak dimengerti.

4. Memahami dan menerima konsekuensi pelayanan.

5. Mematuhi dan menghormati peraturan rumah sakit.

6. Memperlihatkan sikap menghormati dan tenggang rasa dalam proses bersama tim kesehatan mengelola pasien

7. Memenuhi kewajiban finansial yang disepakati.

B. Penerapan enam sasaran keselamatan pasien dan peran keluarga dalam menjaga keselamatan pasien di pelayanan kesehatan

1. Ketepatan Identifikasi Pasien Pasien dalam keadaan tidak sadar, gelisah, mengalami gangguan penglihatan, gangguan pendengaran, gangguan proses pikir, mendapat obat bius, atau gangguan lain tidak mampu melakukan identifikasi diri dengan benar selain itu pasien yang pindah ruang rawat atau bertukar tempat tidur saat perawatan di rumah sakit berisiko mengalami ketidaktepatan identifikasi, maka rumah sakit menyusun sistem untuk memastikan identifikasi pasien sebagai individu yang akan menerima pelayanan adalah tepat dan jenis pelayanan atau pengobatan terhadap individu tersebut adalah sesuai.

Peran Pasien dan keluarga untuk memastikan ketepatan identifikasi pasien adalah:

a. Memberikan data diri yang tepat pada saat mendaftar sesuai dokumen data diri yang dimiliki. Data utama yang diperlukan adalah nama dan tanggal lahir

b. Selama rawat inap pasien dipakaikan gelang. Pasien dan keluarga harus memahami fungsi gelang dan patuh menggunakan gelang tersebut selama rawat inap karena gelang tersebut dipakai oleh tim kesehatan guna memastikan kebenaran identitas dan faktor 
risiko pasien saat memberikan pelayanan. Gelang warna biru untuk laki-laki dan gelang warna merah muda untuk perempuan dipakai untuk identifikasi. Gelang warna merah dipasangkan pada pasien yang memiliki riwayat alergi . Gelang warna kuning dipasangkan pada pasien yang memiliki risiko jatuh

c. Pasien atau keluarga kooperatif saat dilakukan verifikasi identitas oleh petugas saat akan melakukan tindakan, memberikan obat, mengambil preparat untuk pemeriksaan laborat dan lain-lain.

\section{Komunikasi efektif}

Pasien yang menjalani rawat inap dikelola oleh dokter dan berbagai profesi lain sebagai tim dengan menerapkan sistem komunikasi yang efektif untuk memberikan pelayanan.

Peran pasien dan keluarga mewujudkan komunikasi efektif adalah:

a.Menunjuk atau menetapkan anggota keluarga yang diberi kewenangan untuk berkomunikasi dengan tim kesehatan. Penunjukkan ini diperlukan untuk memastikan komunikasi berlangsung efektif dan berkesinambungan, tidak mengalami rantai komunikasi yang panjang dan kompleks yang berisiko menyebabkan perubahan makna isi informasi.

b.memberikan informasi dan data terkait kondisi pasien kepada tim kesehatan dengan benar dan jelas.

c.Memberikan informasi pada petugas bila ada kejadian tidak diharapkan.

d. Meminta informasi yang diperlukan kepada tim kesehatan

3. Pemberian obat secara aman.

Pemberian obat merupakan bagian yang mengambil porsi dominan dalam tata kelola pasien rawat inap.

Peran serta keluarga dalam menjamin keamanan pemberian obat adalah

a. Memberikan informasi yang lengkap tentang riwayat obat yang pernah dipergunakan sebelum masuk rumah sakit 
b. Memberikan informasi tentang riwayat alergi atau reaksi yang dialami saat menggunakan obat tertentu

c.Mendukung pengawasan pemberian obat selama rawat inap dengan cara memastikan identitas pasien benar, menanyakan jenis obat yang diberikan, tujuan pemberian, dosis dan waktu pemberian obat

\section{Kepastian Tepat-Lokasi, Tepat-Prosedur, Tepat-Pasien Operasi.}

Tindakan operasi merupakan salah satu prosedur yang mungkin dilakukan pada pasien untuk mengatasi masalah kesehatannya. Bagian tubuh yang akan dioperasi bisa meliputi bagian yang bersisi (misalnya tangan atau kaki kanan dan kiri, mata kanan dan kiri) atau bagian yang multipel level (misalnya tulang belakang) atau bagian yang multipel struktur (misalnya jari tangan) dengan demikian diterapkan sistem untuk memastikan tindakan tepat-lokasi, tepatprosedur, tepat-pasien .

Salah satu prosedur yang dilakukan sebelum tindakan operasi adalah proses verifikasi. Peran pasien dan keluarga dalam proses verifikasi praoperasi adalah memberikan informasi yang benar dan bekerja sama secara kooperatif Proses yang dilakukan meliputi

a. Verifikasi lokasi, prosedur, dan pasien yang benar Proses ini dilakukan dengan membuat tanda pada lokasi yang dioperasi. Penandaan lokasi operasi ini melibatkan pasien, dibuat oleh dokter yang akan melakukan tindakan dan dilaksanakan saat pasien dalam keadaan sadar .Tanda ini tidak boleh dihapus dan harus terlihat sampai saat akan disayat.

b. Memastikan bahwa semua dokumen, foto (imaging), hasil pemeriksaan yang relevan tersedia, diberi label dengan baik

c. Melakukan verifikasi ketersediaan peralatan khusus yang dibutuhkan.

\section{Pengurangan risiko infeksi terkait pelayanan kesehatan .}

Rumah sakit merupakan tempat yang memungkinkan berkumpulnya berbagai jenis kuman sedangkan pasien yang sedang dirawat memiliki daya tahan tubuh relatif rendah dengan demikian diperlukan suatu proses bersama untuk mencegah timbulnya infeksi lain yang tidak berhubungan dengan penyakit utama pasien. 


\section{PENUTUP}

Menurut Bennett N.B. Silalahi dan Rumondang (1991:22 dan 139) menyatakan keselamatan merupakan suatu usaha untuk mencegah setiap perbuatan atau kondisi tidak 6 selamat yang dapat mengakibatkan kecelakaan sedangkan kesehatan kerja yaitu terhindarnya dari penyakit yang mungkin akan timbul setelah memulai pekerjaannya. Banyak macam penyakit yang diakibatkan karena kecelakaan kerja, sehingga dari program keselamatan kerja itu sendiri memiliki tujuan yaitu untuk mengurangi bahkan menghindari agar tidak ada terjadi kecelakaan yang dapat menimbulkan penyakit pada pekerjanya. Dalam melakukan program keselamatan kerja, diadakan suatu hubungan segitiga yang saling bergantungan yaitu kolaborasi dari berbagai tim medis dengan pasien dan keluarganya, karena dalam hal ini dukungan atau motivasi keluarga juga dibutuhkan untuk keselamatan pasien. 


\section{DAFTAR PUSTAKA}

1. Anggraeni, M. D., \& Ekowati, W. (2010). Peran keluarga dalam memberikan dukungan terhadap pencapaian integritas diri pasien kanker payudara post radikal mastektomi. Jurnal Keperawatan Soedirman, 5(2), 105-114.

2. Arumsari, D. P., Emaliyawati, E., \& Sriati, A. (2017). Hambatan komunikasi efektif perawat dengan keluarga pasien dalam perspektif perawat. Jurnal Pendidikan Keperawatan Indonesia, 2(2), 104-114.

3. Astuti, T. P. (2013). Analisis Penerapan Manajemen Pasien Safety dalam Rangka Peningkatan Mutu Pelayanan di Rumah Sakit PKU Muhammadiyah Surakarta Tahun 2013 (Doctoral dissertation, Universitas Muhammadiyah Surakarta).

4. Banjarnahor, S. (2019). PELAKSANAAN SASARAN KESELAMATAN DALAM MENCEGAH TERJADINYA CEDERA PADA PASIEN DI RUMAH SAKIT.

5. Harefa, E. I. J. (2019). Peningkatan Pelaksanaan Keselamatan Pasien Dalam Pelayanan Kesehatan di Rumah Sakit

6. Hapsari, R. W. (2013). Hubungan Peran Perawat Sebagai Edukator Dengan Pemenuhan Kebutuhan Rasa Aman Pasien di Ruang Rawat Inap Rumah Sakit Umum dr. H. Koesnadi Kabupaten Bondowoso.

7. Kosasih, C. E., \& Purba, C. I. (2018). Pengaruh Edukasi Kesehatan Terhadap Pengetahuan Pasien Stroke dan Keluarga: Peran, Dukungan, dan Persiapan Perawatan Pasien Stroke di Rumah. Media Kesehatan Politeknik Kesehatan Makassar, 13(2), 8-13

8. Oktaviani, R. D. (2019). EDUKASI PERAWAT TERHADAP SASARAN KESELAMATAN PASIEN DI RUMAH SAKIT AGAR TERCIPTANYA PELAKSANAAN TINDAKAN YANG TEPAT.

9. Sari, C. W. M., Haroen, H., \& Nursiswati, N. (2016). Pengaruh Program Edukasi Perawatan Kaki Berbasis Keluarga terhadap Perilaku Perawatan Kaki pada Pasien Diabetes Melitus Tipe 2. Jurnal Keperawatan Padjadjaran, 4(3).

10. Simamora, R. H. (2019). Buku ajar pelaksanaan identifikasi pasien. Uwais Inspirasi Indonesia.

11. Supriyadi, P. B., Kasjono, H. S., \& Werdani, K. E. (2017). Penerapan Manajemen Keselamatan Pasien dalam Usaha Pencegahan Kejadian Pasien Jatuh di Rumah Sakit Islam Klaten (Doctoral dissertation, Universitas Muhammadiyah Surakarta). 